可視化情報 Vol.24 Suppl. No.2（2004 年 9 月）

A 131

空調機の吹出しが室内環境におよぼす影響

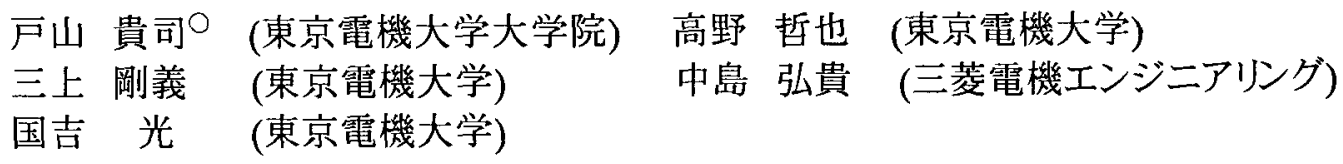

\title{
Flow in the Room affected by Air from Air-conditioner
}

\author{
Takashi TOYAMA , Tetuya TAKANO , \\ Takayoshi MIKAMI , Hiroki NAKAJIMA , Hikaru KUNIYOSHI
}

\begin{abstract}
In this research, the air flow of an air-conditioner is quantified and it is the purpose to save the energy by searching for an optimal conditions which are supply air velocity and angle. It experiments about the model room which diminished to one sixth toward the wall tapestry air-conditioner. A laser light sheet is irradiated for the supply air flow and is visualized. The general characteristic of an air flow is analyzed by the PIV method. The flow in the simple model room which without anything indoors was studied to the former. However, in actual room, various objects are placed indoors, and the influence cannot be disregarded. Then, by this report, two types of the objects is placed indoors and it compare with the simple model without an object. As the result, when an object is installed, it is understand that a flow diffused and it spread indoors.
\end{abstract}

Keywords : Air-conditioner, Supply air flow, Archimedes number, Particle Image Velocimetry (PIV)

\section{1. 緒 言}

快適な室内環境を維持するために, 様々な空調機の開発 が行われている(1). 空調機の吹出し気流は, 非等温流れの ため, 複雑な気流特性をもち, 解析が困難である. そのため, 本質的な室内空間の流れ場の解析はあまり行われていない. しかしこれらの解析は, 効率のよい省エネルギの空調機の開 発に対して重要な役割を果たす.

本研究では，壁掛け式エアコンについて室内を縮小した モデル実験を行うことで, 空調機の吹出し気流(暖房時, 非 定常流れ)の一般的特性について解析する. 著者ら(1)(2)は何 もない単純モデル空間における流れの一般的特性を研究し てきた.しかし実際の居住空間では様々な物が置いてあり， その影響を無視できない. そこで本報告は室内に物体を設 置し, 何もない状況と比較することで, 単純モデルでの実験 をより居住空間に近づけることを目的とする.

\section{2. モテル化}

実物の部屋 $(8$ 畳)の縮尺 $1 / 6$ の室内モデル $(V=600 \times 600$ $\times 400 \mathrm{~mm})$ を製作し, 空調機のモデル化で一般的に使用さ れる浮力と慣性力の無次元数であるアルキメデス数(以下, $A r$ 数 $)^{(3)}(A r=$ 強風 0.0331 , 弱風 0.0654)を実機と一致させ 実験を行った。室内モデル内に実機において吸気口に相 当する排気口(74× $14 \mathrm{~mm})$ を設けた. 室内床面に設置する
物体は，人物を想定した縦型物体 $(67 \times 30 \times 283 \mathrm{~mm})$ と机 を想定した横型物体 $(167 \times 167 \times 67 \mathrm{~mm})$ を用いて実験を行 った.

$$
A r=g \cdot D_{0} \cdot \frac{\Delta T}{v_{y}^{2} \cdot T}
$$

$T:$ Room temperature (K) $D_{0}:$ Equivalent diameter (m) $v_{y}$ : Initial velocity $(\mathrm{m} / \mathrm{s}) \quad g$ : Gravity acceleration $\left(\mathrm{m} / \mathrm{s}^{2}\right)$ $\Delta T:$ Temperature difference of initial air flow $(\mathrm{K})$

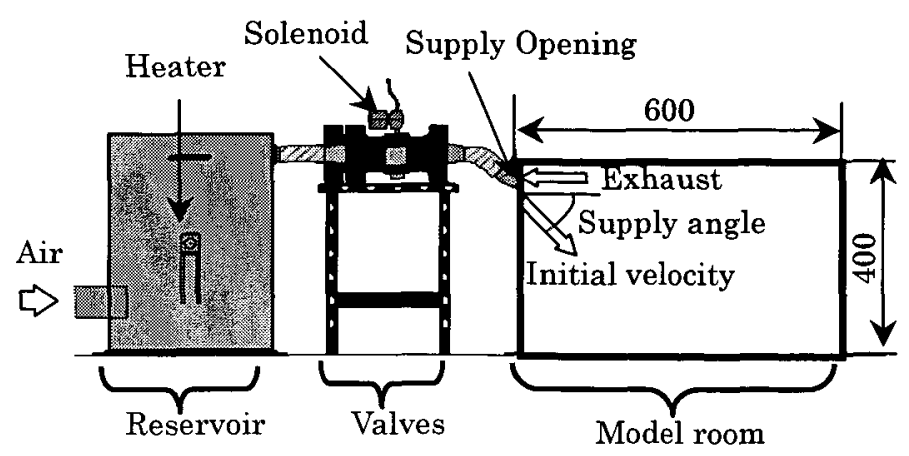

Fig.1 Experimental apparatus 


\section{3. 実験装置および方法}

実験装置は,リザーバ部, バルブ部, モデル部から構成さ れる(Fig.1)、リザーバ部においてトレーサとしてグリセリンミ ストを含んだ空気をヒ一タにより加熱し，吹出し速度を調節 するために圧力を調整する. バルブ部(電磁弁)を開いてモ デル部に空調機を想定した吹出し気流を壁I 上部に設け た $(Z=370 \mathrm{~mm})$ 吹出し口(吹出し口面積 $A=11 \times 54 \mathrm{~mm}$, 吹 出し口相当值径 $D_{0}=275 \mathrm{~mm}$ ) 吅吹出す. このとき, 横型お よび繸型物体を, 室内モデル中央に設置する(Fig.2)

流れの様子について，Ar+レーザ(2W)より LLS(Laser Light Sheet)を解析断面(吹出し軸断面 $600 \times 400 \mathrm{~mm}$ )に 照射して可視化する. 解析位置は, 吹出し軸断面と平行で 壁から中央に向かって $Y=0$ (壁), $100,200,300 \mathrm{~mm}$ (吹出 し軸中心)よする. 可視化された断面をデジタルビデオカメラ (720×480 pixel, フレーム数 1/30s)を用いて撮影する. 撮 影された画像を PIV を用いて解析する. 解析対象となる画 像は 15× 15 pixel の格子に分割し，これらの格子点につい て 90 枚のべクトルデータを平均して解析した. ただし, 相関 值が低く, 過誤ベクトルと判断されるものは予め除き, 補間 後の速度べクトル線図を示した。

実験条件を Table 1 に示す.なお，吹出し条件は室内之 気流の温度差である吹出し温度(実機では $20 \mathrm{~K}$ に相当)を一 定にして, 吹出し速度 $v o$ を変える.

\section{4. 単純モデルでの実験結果}

物体を設置した場合の流れと比較するために, 室内に何も ない単純モデル空間における吹出し気流の一般的特性を以 下に示す。

\section{1. 吹出し気流の一般的特性}

Fig.3 および Fig.4に物体のない単純モデル空間におけ る, 強風時, 吹出し後 $t=10 \mathrm{~s}$ および $t=60 \mathrm{~s}$ での $Y=300 \mathrm{~mm}$ (吹出し軸断面)の流れのベ外ルを示す.

吹出し角度は $\theta=55^{\circ}$ であるが, 吹出し後 $t=10 \mathrm{~s}$ (Fig.3)の 気流は周囲との温度差から浮力の影響を受け上昇する(4)た め, 吹出し気流中心軸から $Z$ 軸方向(天井方向)へ湾曲して いる. また, 林面に衝突した気流(Fig.3 A 部)は床面に治つ て四方八方に広がっていく. $X$ 軸負 (左)方向に流れる気流 は $X$ 軸正(右)方向よりも流速は遅く, 壁I に到達するまで時 間がかかる. 壁Iに到達した気流は壁Iにに治って $Z$ 軸方向 に上昇する.この際，壁から離れていく気流は $X$ 軸負(左)方 向へ流れる.

吹出し後 $t=60 \mathrm{~s}$ (Fig.4)では床面に衝突した気流が四方八 方に広がり, 壁Iに達した気流は吹出し気流の影響を受け て時計回りの渦を形成している(Fig.4 B 部). 一方, 壁IIに 達した気流は壁II に沿って $Z$ 万向に上昇するが, 壁から離 れていく気流が $X$ 軸負(左)方向八流れ，吹出し気流の影響 からそれに巻き込まれて再び床面へ衝突している(Fig.4 C 部). すなわち, 気流が室内に流れの循環を起こしている.

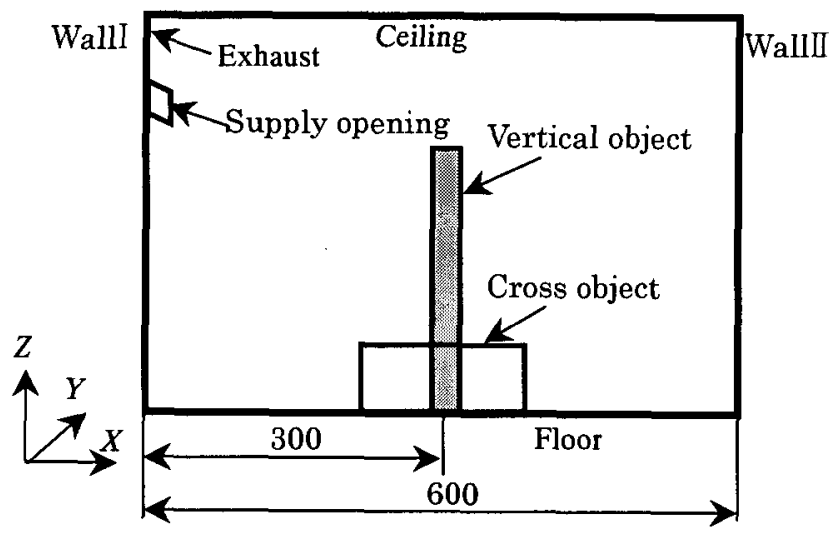

Fig.2 Location of object

Table 1 Experimental condition

\begin{tabular}{|lr|c|c|}
\hline & \multicolumn{2}{|c|}{ High flow } & Low flow \\
\hline Analysis model & $(\mathrm{mm})$ & \multicolumn{2}{|c|}{$600 \times 600 \times 400$} \\
\hline Initial velocity & $\mathrm{v}(\mathrm{m} / \mathrm{s})$ & 0.454 & 0.321 \\
\hline Supply angle & $\theta\left({ }^{\circ}\right)$ & \multicolumn{3}{|c|}{55} \\
\hline Initial temperature difference $\Delta T(\mathrm{~K})$ & \multicolumn{2}{|c|}{5} \\
\hline Archimedes number & $A r$ & 0.0331 & 0.0654 \\
\hline Supply Opening size & \multicolumn{2}{|c|}{$54 \times 11$} \\
\hline Exhaust vent size & \multicolumn{2}{|c|}{$74 \times 14$} \\
\hline Vertical object (human model) $(\mathrm{mm})$ & \multicolumn{2}{|c|}{$67 \times 30 \times 283$} \\
\hline Cross object (desk model) & $(\mathrm{mm})$ & \multicolumn{2}{|c|}{$167 \times 167 \times 67$} \\
\hline
\end{tabular}

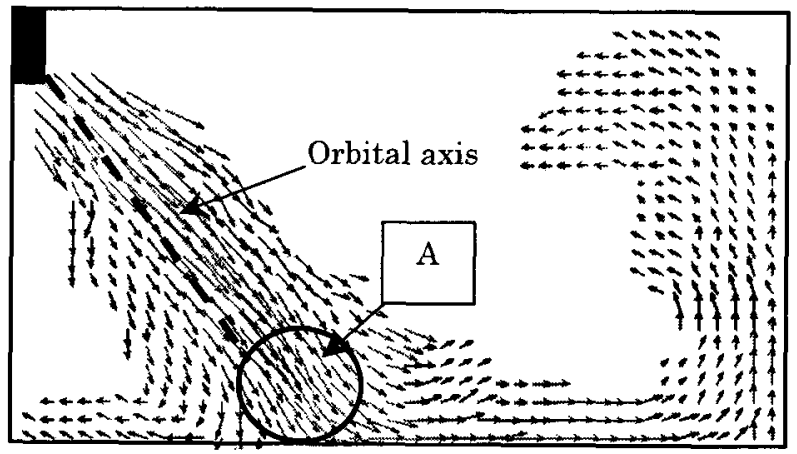

Fig.3 Velocity vector (High flow, $\theta=55^{\circ}, t=10 \mathrm{~s}$ )

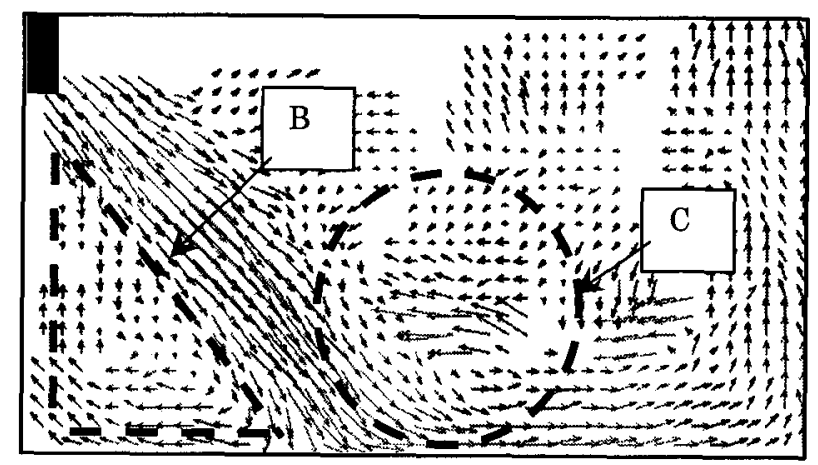

Fig.4 Velocity vector (High flow, $\theta=55^{\circ}, t=60 \mathrm{~s}$ ) 


\section{2. 室内文流分布の定量化(流動率)}

室内気流分布の割合を定量的に評価するために, 室内空 間を, (I )人が生活しない領域(天井付近)，(II )人が立った 時に顔に気流が当たる領域, (III)顔より下の上半身の領域, (IN)床面から足下付近の領域と高さ方向に 4 分割した (Fig.5). 解析方法は, PIV により求まった速度をもとに, 領 域内で気流の流動が見られる速度 $(v \geqq 0.002 \mathrm{~m} / \mathrm{s})$ が占める 面積の割合を求める. 各領域において, 流動している割合 (\%)を示した(Fig.6). 評価対象断面は，吹出乙軸断面之平行 で壁から中央に向かう複数断面で, (i) $Y=0 \mathrm{~mm}$ (壁)，

(ii) $Y=100 \mathrm{~mm}$, (iii) $Y=200 \mathrm{~mm}$, (・) $Y=300 \mathrm{~mm}$ (室内中央 の吹出し軸断面)とする.

強風時の流動率について考察する. 強風時では気流は 室内下部への流動が大きい. また, $Y=0 \mathrm{~mm}$ (壁際)では, 他 の解析断面に比べ大きな值をとっている.この 2 点から, 床 面に衝突した吹出し気流は室内の四方の壁に沿って上昇す ることがわかる. 弱風でも室内下部への流動が大きい.しか し, 強風では壁端に近い断面の流動が大きいのに対し, 弱 風では室内中央の断面の流動が大きい.このように, 強風で は気流が室内の四方の壁に治って上昇するのに対し, 弱風 では室内中央で上昇することがわかる．

$t=10 \mathrm{~s}$ における室内気流の流動割合では, 強風に比べ て弱風の流動は小さい.しかし $t=60 \mathrm{~s}$ にお污る室内気流 の流動割合では，全体的な流動割合が強風・弱風ともに $80 \%$ 前後となり，互いにほほ等しくなる.つまり，電力 の有効利用や電気代などを考慮した効率的なエアコンの 使用を考えた場合，はじめは強風を用いて，時間の経過 に伴って弱風に切替えることが適切であることを示して いる.

\section{5. 物体を設置した場合}

\section{1. 物体が流れに及ぼす影響}

Fig.7に強風時, 吹出し角度 $\theta=55^{\circ}$, 吹出儿後 $t=10 \mathrm{~s}$ に おける横型物体設置時の流れのべクトル(吹出し口を通る中 央断面)を示す.また同条件における縦型物体設置時の流 れのベ外ルを Fig.8に示す.

横型物体がある場合では，ない場合の=60s で見られた吹 出し口直下での大きな時計回りの渦が $\mathrm{t}=10 \mathrm{~s}$ に見られる (Fig.7 D 部).これは物体に衝突した際に $X$ 軸負(左)方向へ と進む流れが，物体がない場合に比べ増加するためである. またその流れとは別に,物体に衝突後,そのまま $X$ 軸正(右) 方向へと直進し，壁II汾って Z軸正(天井)方向へと上昇す る流れが存在する.この気流は, 天井まで到達した後, 物体 がない場合と同様に $X$ 軸負(左)方向へ流れる.

縦型物体がある場合では，吹出された気流は物体の下部 に吸い込まれるように流れ，その先が途絶えているように見 える(Fig.8 E 部).これは物体に衝突後 $Y$ 軸方向(紙面奥行 方向)へ流れているためである. $Y$ 軸方向へ流れた気流はそ のまま側面の壁へと衝突し, 壁に治って上昇し天井まで到達

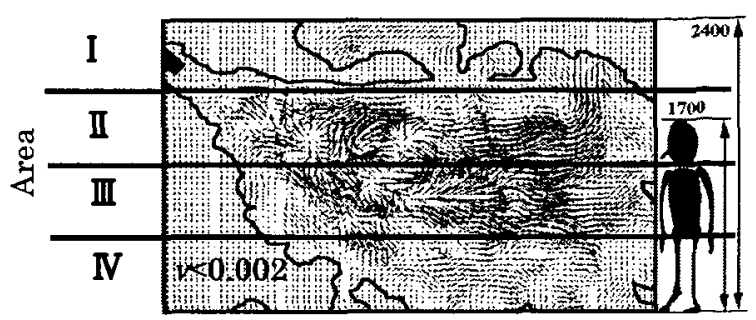

Fig.5 4Areas in the room

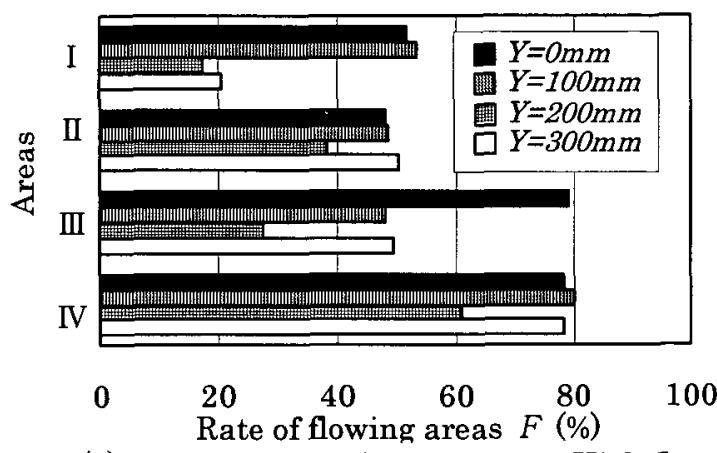

(a) Time after supply start $t=10 \mathrm{~s}$, High flow

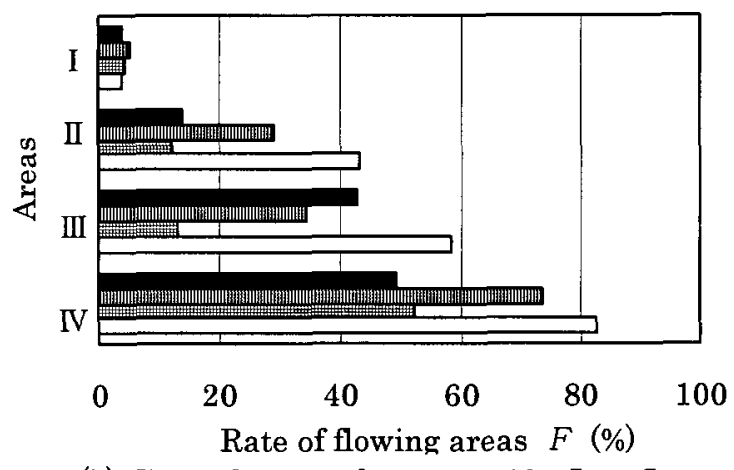

(b) Time after supply start $t=10 \mathrm{~s}$, Low flow Fig.6 Rate of flow distribution

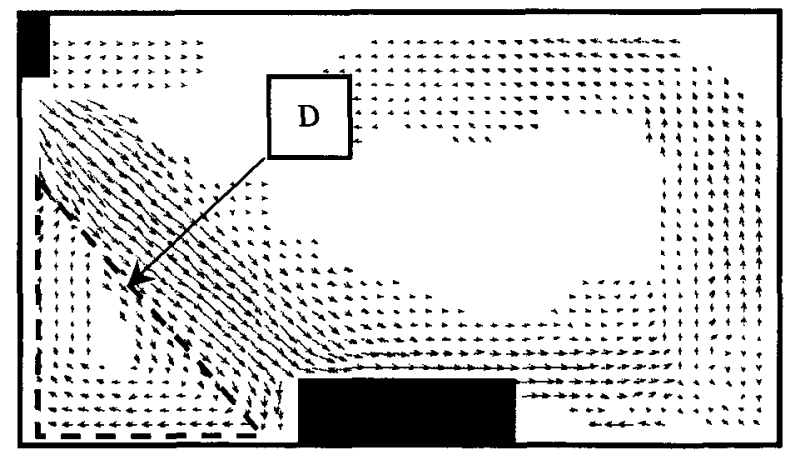

Fig.7 Velocity vector (Cross object, High flow, $\theta=55^{\circ}, t=10 \mathrm{~s}$ )

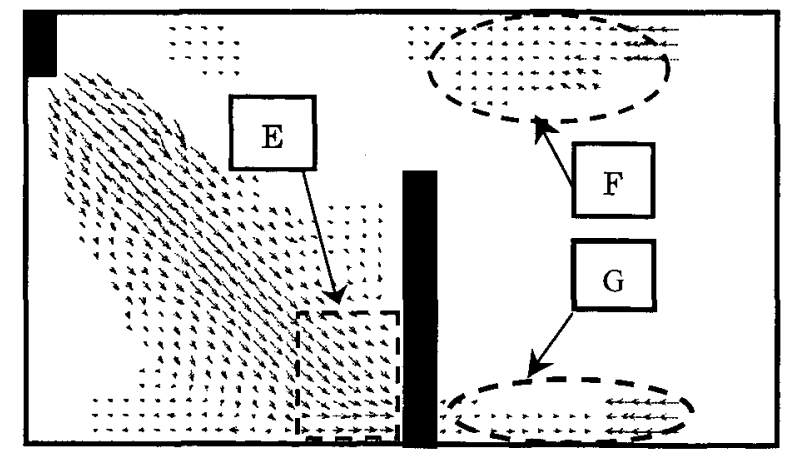

Fig. 8 Velocity vector (Vertical object, High flow, $\theta=55^{\circ}, t=10 \mathrm{~s}$ ) 
した後, 室内中央へと流れる(Fig.8 F 部). その気流とは別 に, 物体を巻くように流れる気流も存在する(Fig.8 G 部).

\section{2. 室内気流分布の定量化(流動率)}

物体設置時の流動率を Fig.9 に示す. 横型物体がある場 合では，物体がない単純モデル空間(Fig.6)と比べ, $Y=300 \mathrm{~mm}$ (室内中央部)での流動が大きい。これは吹出し 口直下での渦とそのまま直進し壁II に沿って $Z$ 方向に上昇 する流れが発生するため, 室内全体へと流れが搪散し, 流動 率が大きくなるためである. 縦型物体がある場合では， $Y=0$ mm断面が, 領域では領域I と領域IVの流動が大きい.これ は前述したように, 縦型物体に衝突後, 床面に沿って $Y$ 軸方 向(紙面奥行方向)に気流が，壁にそって上昇し，天井付近 を通って室内中央へと流れ込むためである.

また Fig.10に時間経過による室内全体の流動率の変化を 示す.これは Fig.9で求めた4つの断面について流動率を平 均し，物体設置時と物体がない単純モデル時を比較したもの である. 強風時, 弱風時ともに $t=60 \mathrm{~s}$ 以前においては, 流動 率は物体がある方が, 物体がない状態に比べ約 2 割大きな 値となる.これは気流が物体に衝突した際に，様々な向きに 流れが拡散し，室内に広がるためである.

$t=60 \mathrm{~s}$ 後には, 物体のない場合之物体を床面に設置した 場合とでは, 流動率に差がなくなっている.このように物体の 設置によって流動率が影響を受けるのは $t=60 \mathrm{~s}$ までであり, それ以降は物体のない状態と同じになる。

強風之弱風を比べると, 弱風の方が全体的に值は小さい. また, $t=60 \mathrm{~s}$ 以前において, 強風では横型物体が綎型よりも 大きな值を示すのに対し, 弱風では逆になっている. 弱風の 場合怡強風よ浮力の影響を強く受け, 流れが $Z$ 軸正(天井) 方向へと湾曲するため, 横型物体と衝突する際に D 部への 流れが少なくなり， $X$ 軸正(右)方向への流れが多くなる.この ため, 横型物体設置状熊の流れは物体がない状態の流れに 近くなり, 值が低くなる.

\section{6. 結 言}

実物の部屋に対してアルキメデス数を一致させた縮小モデ ル内の床面に, 物体を設置した状態で温風を吹出し, PIV を用いた画像解析により室内気流分布を解析し, 以下の結 果を得た。

（1）流動率は, 吹出し後 60 s以前では, 物体のない状態に 比べて 2 割程度大きい。

（2）流動率は, 吹出し後 60s以降, 物体のない状態と同じ になる.

\section{参考文献}

（1）高橋ら, 空調機の吹出しが室内流れにおよほす影響, 可視化情報 三重講演会講演論文集, Vol.17, Suppl.No.2, (1998), 87-88.

（2）中島弘貴，空調機の吹出しが室内環境におよほす影響，鹿児島地 万講演会講演論文集, No.38(2003-10), 135-136.

（3）井上宇市, 空気調和ハンドブック，(1995)，367, 丸善株式会社.

（4）空気調和・衛生工学会, 空気調和・衛生工学便覧II 巻, (1981), II - 209, 小薬印刷所、

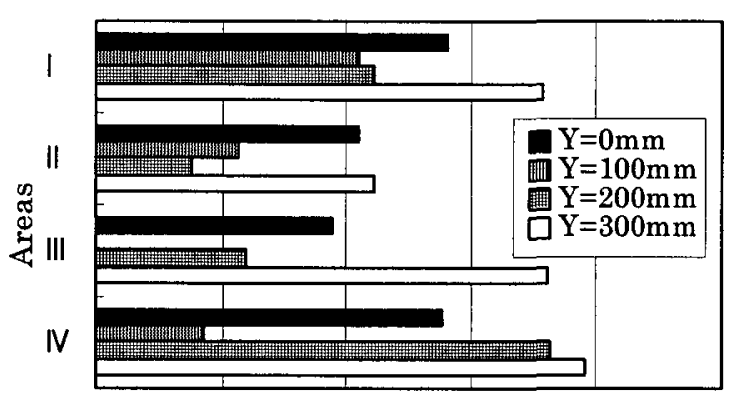

$\begin{array}{llllll}0 & 20 & 40 & 60 & 80 & 100\end{array}$

Rate of flowing areas $F(\%)$

(a) Cross object, High flow, $\theta=55^{\circ}, t=10 \mathrm{~s}$

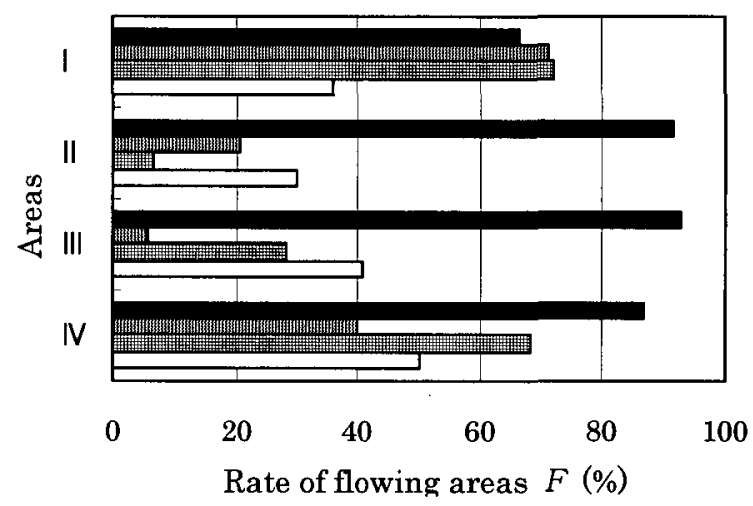

(b) Vertical object, High flow, $\theta=55^{\circ}, t=10 \mathrm{~s}$

Fig.9 Rate of flow distribution

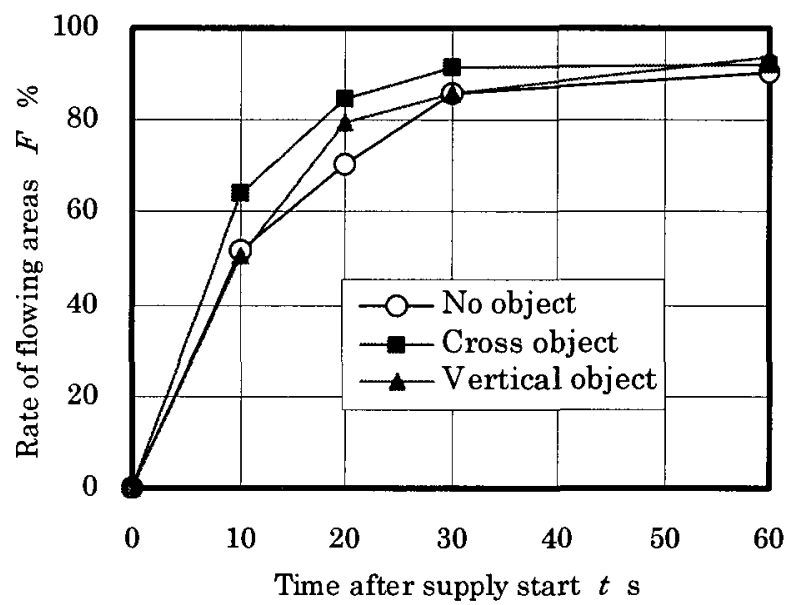

(a) High flow

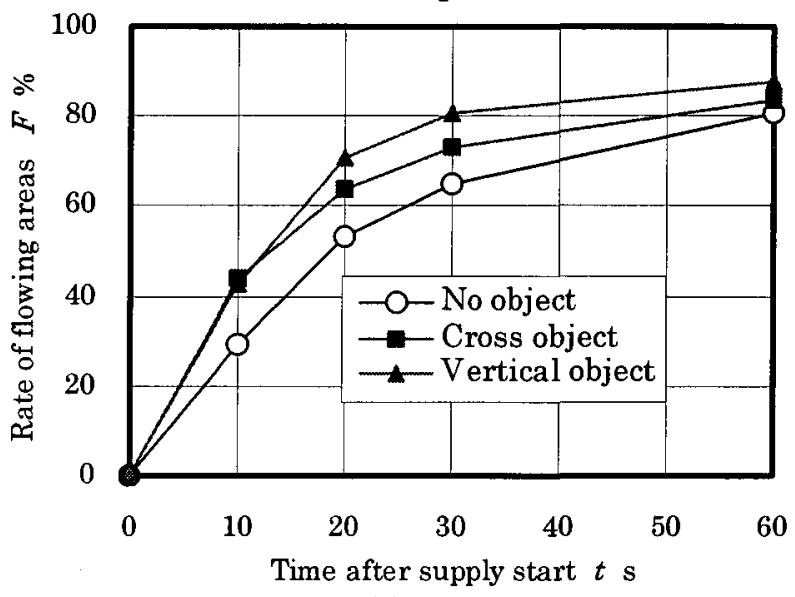

(b) Low flow

Fig.10 The Change of rate of flow distribution 